\title{
Preferential feeding by the crab Necora puber on differing sizes of the intertidal limpet Patella vulgata
}

\author{
A. C. Silva ${ }^{1,2, *}$, S. J. Hawkins ${ }^{2,3}$, K. R. Clarke ${ }^{2,4}$, D. M. Boaventura ${ }^{5,6}$, R. C. Thompson ${ }^{1}$ \\ ${ }^{1}$ Marine Biology \& Ecology Research Group, Marine Institute, University of Plymouth, Drake Circus, Plymouth PL4 8AA, UK \\ ${ }^{2}$ Marine Biological Association of the United Kingdom, Citadel Hill, Plymouth PL1 2PB, UK \\ ${ }^{3}$ School of Ocean Sciences, Bangor University, Menai Bridge, Ynys Mon LL59 5AB, UK \\ ${ }^{4}$ Plymouth Marine Laboratory, Prospect Place, Plymouth PL1 3DH, UK \\ ${ }^{5}$ Escola Superior de Educação João de Deus, Av. Álvares Cabral 69, Lisbon 1269-094, Portugal \\ ${ }^{6}$ Laboratório Marítimo da Guia, Centro de Oceanografia da Faculdade de Ciências da Universidade de Lisboa, \\ Avenida Nossa Senhora do Cabo 939, 2750-374 Cascais, Portugal
}

\begin{abstract}
The crab Necora puber L. is a common predator of limpets, the major grazer on rocky shores in Northern Europe. Information on interactions between crabs and their limpet prey is limited, extending mainly to limpet defensive and predator offensive tactics, while the importance of prey size on the outcome of such interactions remains largely unknown. Here, a laboratory approach was used to test for preference in feeding habits. Predation by N. puber with cheliped height 3 to $27 \mathrm{~mm}$ (carapace width [CW]: 16 to $77 \mathrm{~mm}$ ) was examined on Patella vulgata with shell length 5 to $60 \mathrm{~mm}$. Predator size $(10,11-15,16-20$ and 21-25 mm cheliped height) and prey size (5-10, 15-20, 25-30 and 35-40 mm shell length) were examined, with 2 replicate tests for each predator-prey size combination. Crabs $>10 \mathrm{~mm}$ in cheliped height $(35 \mathrm{~mm} \mathrm{CW}$ ) predominantly crushed the shell of limpets $<10 \mathrm{~mm}$, while in the remaining combinations of predator and prey sizes, crabs prised limpets from the substratum. Size of limpet shell (vulnerability to crushing force) and resistance to leverage force were both important factors influencing the outcomes of crab-limpet interactions. For the largest crab tested $(27 \mathrm{~mm}$ cheliped height; $77 \mathrm{~mm} \mathrm{CW})$, there was a size refuge for limpets $>41 \mathrm{~mm}$ in shell length. Field observations showed that the majority $(94 \%)$ of limpets present in the intertidal zone are of a size that is vulnerable to predation by $N$. puber. For all sizes of crab examined, there were clear preferences for limpets smaller than the maximum size that the crabs were actually able to consume. Intriguingly, however, the preference experiment showed that, when given a choice, crabs consistently consumed proportionately more limpets of a larger size-class than when presented only with a single size-class at a time. Although further in situ studies are necessary, the present study indicates that size-selective predation by $N$. puber and other crabs may have an important influence on limpet population structure.
\end{abstract}

KEY WORDS: Handling behaviour $\cdot$ Intertidal $\cdot$ Size refuge $\cdot$ Size preference

\section{INTRODUCTION}

Predicting the effects of predators on prey populations requires a broad understanding of predator choice in relation to prey type and size (Sih et al. 1985). Most predators exhibit some form of selective feeding behaviour (for predation by crabs, see e.g. Hughes \&
Elner 1979, Hughes 1980, 2000, Seed \& Hughes 1995, 1997). As a consequence, prey are not necessarily consumed according to their relative abundance (Singer 2000, Underwood et al. 2004). The profitability of consuming a particular prey depends on the balance between handling costs and the net energy gain and this varies, for example, seasonally in relation to 
reproductive cycles, temperature and according to prey size.

Many crabs select their prey according to type and/ or size (Hughes \& Elner 1979, Seed \& Hughes 1995, 1997, Yamada \& Boulding 1998, Hughes 2000). Predator choice in relation to prey size has been investigated for interactions between intertidal crabs and various species of coiled gastropods (e.g. Vermeij 1977, 1978, Hughes \& Elner 1979, Vermeij et al. 1981, Chilton \& Bull 1986, Yamada \& Boulding 1998, Jackson \& Underwood 2007) or bivalves (Hughes \& Seed 1981, ap Rheinallt 1986). However, despite considerable evidence that limpets are an important component of the diet of crabs (Lowell 1986, Iwasaki 1993, Cannicci et al. 2002, Silva et al. 2008), predatory interactions between crabs and limpets have not been extensively examined (but see Lowell 1986, Iwasaki 1993, Silva et al. 2004, 2008).

Recent work using exclusion cages has shown that predation by crabs, and to a lesser extent by small fish such as blennies, has a significant impact on the abundance of limpets on shores in southwest Britain and especially on smaller individuals (see Silva et al. 2008). Size-selective predation by crabs can influence the population structure of gastropod prey such as Nerita atramentosa (Reeve) and Bembicium nanum (Lamarck) (Chilton \& Bull 1984). Hence, it is possible that crabs may exert similar pressure on populations of limpets. Furthermore, patellid limpets have been shown to compete intraspecifically between sizes (Boaventura et al. 2003) and so, selective predation may also indirectly influence competitive interactions by altering the relative abundance of some species and of some size-classes (see Menge \& Sutherland 1976, 1987). Limpets are crucial grazers in the intertidal zone and can control the abundance of micro- and macroalgae (Hawkins \& Hartnoll 1983, Hawkins et al. 1992, Boaventura et al. 2002a, Thompson et al. 2004, Jenkins et al. 2005, Coleman et al. 2006); therefore, knowledge about the impact of predation on these grazers is important to our understanding of intertidal ecology.

Necora puber is a commercially important species in Europe (ICES catch data, www.ices.dk) and is abundant on the lower shore and shallow subtidal zone throughout the northeast Atlantic (Clark 1986). In the intertidal zone, it forages mainly during nocturnal high tides when it undertakes foraging excursions up the shore, and it is known to consume limpets in the intertidal zone during high tide (Norman \& Jones 1992, Silva 2008). Studies of stomach contents of N. puber in southwest Britain indicate that limpets may constitute up to $30 \%$ of its diet (Silva 2008). Based on preliminary observations of $N$. puber and related species such as Carcinus maenas L. (Silva 2008), we predicted that predator handling behaviour would vary according to prey size whereby smaller limpets would be crushed and larger limpets prised from the substratum (as observed by Lowell 1986, Iwasaki 1993). Such behaviour would be comparable to that shown by crabs when handling snails or bivalves, where smaller individuals are crushed while larger ones have their shell peeled (e.g. ap Rheinallt 1986, Freire 1996, Yamada \& Boulding 1998). It is reasonable to assume that crabs exert more effort in order to attack larger limpets (e.g. longer handling times) and that this cost may influence their choice of prey. Similar effects have been observed with bivalve prey (e.g. mussels: Hughes \& Seed 1981, 1995) or snails such as Littorina sitkana Philippi (Yamada \& Boulding 1998). Hence, it may be disadvantageous for crabs to attack large limpets and they may also be unsuccessful attacking limpets above a threshold size, hence leading to a size refuge from predation.

Here, we assessed the importance of size-selective foraging by crabs on limpet prey using laboratory experiments with the crab Necora puber and the limpet Patella vulgata. We examined whether observations from field experiments that indicated that crabs exert stronger predation pressure on smaller limpets (see Silva et al. 2008) were associated with predator preference for smaller size-classes. We also examined whether there is a size refuge for limpets from N. puber.

The approach to designing predator choice experiments advocated recently by Underwood \& Clarke (2005) was adopted, with some modifications. This design allows testing for preference in feeding behaviour by comparing the number of limpets eaten when a predator is given no choice (e.g. for prey type or size) with the number of limpets eaten when a predator is given a choice. The following null hypotheses were examined: (1) Patella vulgata does not have a size refuge from predation by Necora puber, (2) N. puber has no preference for a particular size of limpet, and (3) there are no differences in attack behaviour between small and large prey whereby the crab prises the shell from the substratum with the tip of the cheliped.

\section{MATERIALS AND METHODS}

Species and collection sites. Male crabs, size range 4 to $27 \mathrm{~mm}$ in major chela height (16 to $77 \mathrm{~mm}$ carapace width [CW]), were collected during June and July 2007 from Mount Batten in southwest Britain $\left(50^{\circ} 21^{\prime} \mathrm{N}\right.$, $4^{\circ} 07^{\prime} \mathrm{W}$ ), where they have previously been shown to feed on limpets (Silva 2008). Males were used as they were the most abundant sex on the shore, hence the present study did not examine differences in preference behaviour with gender. The master cheliped height, rather than CW, was used as a measure of crab 
size, because chelipeds are used by Necora puber to attack limpets (Freire et al. 1996, Silva 2008), and cheliped size and in particular height directly determine the size of prey that can be consumed by means of grasping or crushing (see Lee \& Seed 1992, Yamada \& Boulding 1998). Hence, we considered that measuring cheliped height might reduce a potential source of variation in our data.

Any crabs with missing limbs or parasitic infestation were rejected as there was no available literature describing the crab body parts involved in limpet attack, and infested crabs potentially have altered feeding behaviour (e.g. Elner \& Raffaelli 1980). The remainder were divided into 4 size-classes based on the height of their major cheliped $(\leq 10,11-15,16-20$ and 21-25 mm). Care was taken to collect individuals that represented the majority of sizes naturally present on the shore (based on Silva 2008).

The limpet Patella vulgata was used as prey because it was the most abundant species of limpet on the shore where the crabs were collected and is widely distributed throughout the northeast Atlantic (Moore et al. 2007). $P$. vulgata was present in a size range from 3 to $66 \mathrm{~mm}$ (average $\pm \mathrm{SE}=18 \pm 0.03 \mathrm{~mm}, \mathrm{n}=156$ ), as determined by preliminary observations using 5 replicate quadrats $(50 \times 50 \mathrm{~cm}$, average limpet density: $18 \pm$ 2 ind. $0.25 \mathrm{~m}^{2}$ ) at each of 2 sites at 2 locations (Mount Batten and Thurlestone, southwest England) in June and July 2007. Limpets of shell length 5 to $60 \mathrm{~mm}$ were collected on the substratum to which they were attached by removing samples of the underlying rock with a hammer and chisel. This method avoids any damage to the mantle or foot, which could affect their ability to attach to the substratum.

Experimental setup. Crabs were maintained in aquaria (length $\times$ breadth $\times$ depth: $60 \times 50 \times 45 \mathrm{~cm}$ ) with 10 ind. $\operatorname{tank}^{-1}$ and where refuges (rocks) were available. Crabs were fed with cockle flesh for 2 wk and then starved for $3 \mathrm{~d}$ to standardise recent experience in prey handling and hunger. Cockles were used because they are common prey of predatory crabs present in southwest England (e.g. Mascaró \& Seed 2001) and represent a different prey of limpets, which could not be used in the experiments as it would represent a confounding element. A constant flow of filtered seawater at $15^{\circ} \mathrm{C}$ was maintained in all tanks. Limpets (together with the underlying rock) of different sizeclasses were kept together in large shallow tanks (length $\times$ breadth $\times$ depth: $150 \times 60 \times 10 \mathrm{~cm}$ ) under similar conditions to crabs.

Behavioural trials were conducted in 101 glass aquaria $(30 \times 40 \times 20 \mathrm{~cm})$. Smooth limestone slabs, similar in surface texture to limpets' natural substratum, were collected from the shore and cut to fit the tank bottom, providing a natural substratum for limpets to attach to. Limpets were transferred to these substrata prior to trials by detaching shells with a slight rotational movement of the shell at times when they were active. Prey were checked for a positive clamping response when disturbed before predators were introduced. Predators were introduced $1 \mathrm{~h}$ before darkness (in a $16 \mathrm{~h}$ light: $8 \mathrm{~h}$ dark photoperiod), and observations were made during darkness, when crabs are most active (Naylor 1958, Hunter \& Naylor 1993, Cannicci et al. 1999). Each predator and each prey were only used once to maintain independence of the data and exclude possibility of modification of behaviour through experience.

Prey were individually tagged with small numbered tags (Brady company, reference TMXM-0-49) to distinguish size-classes during trials and to enable crushed shells to be identified. A preliminary test was made using limpets of the 15 to $20 \mathrm{~mm}$ size-class (vulnerable to all sizes of predator) to confirm that the presence of tags did not influence consumption (tagged vs. nontagged: $F_{1,39}=1.47, \mathrm{p}=0.23 ; \mathrm{n}=20$; preyed limpets (average number $\pm \mathrm{SE}$ ): tagged $=3.8 \pm 0.2$ vs. nontagged $=3.6 \pm 0.4$ limpets) .

Expt 1: size range consumed. The range of limpet sizes that crabs of each size-class (chela height: $\leq 10$, 11-15, 16-20 and 21-25 mm) could consume was examined by presenting progressively increased sizes of limpets to individual crabs. Different crabs were used in each trial to avoid potential behavioural differences due to satiation levels or learned experience. Hence, each crab was only used once with each limpet size in a single test. Crabs were not re-used with the different prey size-classes.

The categories of prey sizes used represented the majority of sizes available on the shore and were: $5-10,15-20,25-30,35-40,45-50$ and 55-60 $\mathrm{mm}$ in shell length. A $5 \mathrm{~mm}$ gap among classes was chosen to increase the contrast between size-classes. Two replicate tests were used for each predator-prey size combination. Trials ran for $48 \mathrm{~h}$ on each combination of predator and prey sizes and the next following limpet size was only used after the previous size had been shown to be eaten.

Expt 2: size preference. In order to examine the preference of Necora puber for limpets of differing sizeclasses, we followed the philosophy, though not the precise analysis, of Underwood \& Clarke (2005), namely that preference is demonstrated only by observing different proportions (in sizes selected) when there is a choice compared to when there is not. In the first stage of a 2-stage experimental procedure, the number of limpets consumed per size-class was quantified when no choice was available to the predator. In the second stage, the proportion of differentsized limpets consumed was determined when choice 
was available. The prey and predator size-classes used were identical to those described for size range trials (Expt 1). Each predator and prey were only used once.

In Stage 1 (with no choice), 2 replicate tests were made for each predator size-class with independent animals in each test. Crabs were allowed to feed for $48 \mathrm{~h}$ on 3 limpets of only 1 size-class per test, within the range they had been shown to handle in Expt 1. For Stage 2 (with size choice), crabs were presented with 3 limpets of all size-classes and again allowed to feed for $48 \mathrm{~h}$ per test. Data from Stages 1 \& 2 were then used to test the null hypothesis that there was no preferential selection of prey according to size, by comparing the proportions consumed of each size class, $\mathrm{k}$, under the 2 stages. This uses a chi-squared test of association in a $2 \times \mathrm{k}$ contingency table, though allowing for small expected values by exploiting permutation tests, rather than invoking a large-sample chi-squared approximation.

Various independence assumptions are required for a valid statistical analysis, so the description of the experimental procedure needs to be unambiguous, and is exemplified here by the case of crabs of the largest size-class, 21-25 mm. Expt 1 demonstrated that all 4 prey size-ranges could be consumed by this size of predators, so 5 crabs (A to E) were randomly selected from the holding tanks. In Stage 1, Crab A was placed for $48 \mathrm{~h}$ in a tank initially containing 3 limpets of the first size-class $(5-10 \mathrm{~mm})$. As a limpet was consumed, it was replaced by another from the same size-range, and the total numbers eaten over $48 \mathrm{~h}$ were recorded (only 1 , in this case). Newly introduced limpets were checked for attachment by trying to pull the shell before allowing predator access, thus maintaining the same level of vulnerability to predation as of those still in the test tank. The attachment times were invariably $<15 \mathrm{~s}$ for all limpets. Crab B was similarly placed for $48 \mathrm{~h}$ in a different tank initially containing 3 limpets of the second size-class $(15-20 \mathrm{~mm})$, which were also replaced as they were consumed (a total of 14 were eaten). Crabs C and D likewise consumed 2 and 1 of the size-ranges 25$30 \mathrm{~mm}$ and $35-40 \mathrm{~mm}$ respectively. In Stage 2 of the experiment, Crab E was placed for $48 \mathrm{~h}$ in a tank containing 3 of each of the 4 prey sizes, limpets again being replaced as consumed, resulting in totals of 1,6 , 14 and 1 individuals consumed from the 4 prey sizeranges.

Clearly, total consumption over $48 \mathrm{~h}$ is not necessarily comparable for Stage 1 \& 2 experiments, so we 'condition on' (remove) this difference by considering only the proportions of each prey size consumed. Under the null hypothesis of 'no preference', sensu Underwood \& Clarke (2005), the proportions $p_{i}$ of prey size $i$ (for $i=$ $1, \ldots, 4)$ consumed under Stage 1 (estimated by 1/18,
$14 / 18,2 / 18$ and $1 / 18$ respectively) should equal the proportions $q_{i}$ of prey size $i$ consumed under Stage 2 (estimated respectively by $1 / 22,6 / 22,14 / 22$ and $1 / 22$ ). In this design, unlike that considered by Underwood \& Clarke (2005), there is no meaningful concept of the number of prey items not consumed, since all prey items were replaced when eaten (in effect, an infinite supply). The resulting chi-squared test is simpler to execute in this case, being just a test for 'association in a $2 \times 4$ contingency table'. The test retains the 2 key features of the Underwood \& Clarke (2005) approach, that: (1) preference is only demonstrated by comparing choice with the absence of choice, and (2) uncertainty in estimation is taken into account for both Stage 1 and Stage 2 experiments (i.e. allowing for estimation error in both $p_{i}$ and $q_{i}$ as one does in a contingency table test).

Crabs from a different size range (e.g. 5 crabs of size $16-20 \mathrm{~mm}$ ) are now selected and the whole of Expt 2 undertaken again, and similarly with the other 2 size ranges (only 4 crabs are needed for the 11$15 \mathrm{~mm}$ range, and 3 for the $\leq 10 \mathrm{~mm}$ range because of the more limited size categories of prey that are ever consumed, as seen in the results of Expt 1). Finally, this whole sequence of 4 Expt 2 designs is repeated once more, again using an entirely different set of crabs, allowing greater reliability of conclusions (and a high degree of consistency in this case; see 'Results'). This also has the advantage of permitting some testing of the implicit assumptions in the analysis, as discussed next.

Expt 2: analysis assumptions. Some of the 'expected' frequencies for the above contingency table test are small, i.e.:

Observed frequencies:

Stage 1: 1, 14, 2, 1; Total: 18

Stage 2: 1, 6, 14, 1; Total: 22

Expected frequencies (under 'no preference'):

Stage 1: $0.9,9.0,7.2,0.9$

Stage 2: 1.1, 11.0, 8.8, 1.1

leading to a chi-squared statistic value of $\chi^{2}=11.9$. However, a chi-squared distribution on $3 \mathrm{df}$ would not be a good approximation to the sampling distribution of $\chi^{2}$ under the null hypothesis because of the low expected frequencies in 4 of the cells. In fact, this assumption is not made because exact p-values can be obtained by permutation. A total of 10000 realisations were made of observed frequencies with the same marginal totals, under the null hypothesis, and the $\chi^{2}$ value calculated for each. Only 12 of these were as large, or larger than, the true $\chi^{2}$ value of 11.9, thus giving $\mathrm{p} \approx 0.0012$, a strong rejection of the null hypothesis.

It is still true, however, that 2 types of approximate independence are necessary for this permutation test 
to be sound. These are the same assumptions made by Underwood \& Clarke (2005), discussed in Manly (2006) and Taplin (2007), and responded to by Underwood \& Clarke $(2006,2007)$. First, the test relies on multinomial distributions for the numbers of limpets consumed of each size-class under the 2 stages (and conditional on the observed total counts for each stage). This corresponds to an assumption that each new selection by an individual crab, over the course of the $48 \mathrm{~h}$ period, is independent of its previous selection (with the same probabilities). Second, crabs of the same size range have the same probabilities of making equivalent choices, all else being equal (in other words, the absence of a 'crab effect').

At least the second of these assumptions is testable here because of the complete repeat of both stages of Expt 2, again with an entirely different set of crabs. This is again exemplified by data from crabs of the largest size class, 21-25 mm, for which 14 limpets of size 15-20 mm were consumed in Stage 1 from the first set of trials, and 12 in Stage 1 from the repeat of this experiment. Under the null hypothesis of 'no crab effect' these are again multinomial (binomial), conditional on the observed total of 26 consumed, with expected values of 13 to match the observed values of 12 and 14, a chi-squared statistic of 0.15 on 1 df. Repeating this calculation for all counts, matched across replicates, from the data in Table 1 (e.g. for Stage 1: 5 with 7,1 with 1,13 with 11,2 with $2, \ldots$, and for Stage 2: 3 with 2, 0 with 1, 3 with 2, 12 with 10, etc.), and adding all the resulting $\chi^{2}$ statistics gives a total $\chi^{2}$ of 9.5 on $26 \mathrm{df}$, under the null hypothesis of 'no crab effect'. This clearly provides no evidence to reject that hypothesis, the value of this goodness-of-fit statistic actually being less than its hypothesised mean. In fact the consistency between the experimental repeats is sufficiently impressive to suggest evidence, perhaps, of the negative correlations, in counts of organisms consumed, postulated by Manly (2006) and discussed by Taplin (2007), but which Underwood \& Clarke (2006) point out would make the tests for preference conservative (i.e. only likely to reject the null hypothesis of 'no preference' when it is very clearly established). And, indeed, the contrasting counts between Stages 1 \& 2, compared with repeats of either Stage 1 or Stage 2, are both very striking and consistent across the 3 larger crab sizes, and their degree of significance is therefore likely to be underestimated.

Expt 3: handling behaviour. To establish whether Necora puber had different handling behaviour according to prey size, video observations were made during the Stage 1 experiment. Quantitative and qualitative observations of prey handling method and time were made for 5 replicate predator-prey pairs for each size combination.

\section{RESULTS}

The cheliped size (major chela height) of Necora puber males was found to be in direct proportion to the width of the animal carapace $\left(\mathrm{r}^{2}=0.94, \mathrm{p}<0.001, \mathrm{n}=\right.$ $20)$, which is the most commonly taken size-measure, suggesting that either measure can be used for this species.

\section{Expt 1: size-range consumed}

The size of Patella vulgata consumed was positively related to the size of the major claw of Necora puber. Regression analysis between the largest limpet eaten and the size of crab claw showed that larger predators were able to consume larger prey, thus supporting our second hypothesis $\left(\mathrm{r}^{2}=0.90, \mathrm{p}<0.001, \mathrm{n}=20\right)$. The largest limpet consumed was $41 \mathrm{~mm}$ by a crab of $25 \mathrm{~mm}$ major cheliped height ( 75 mm CW). Because this crab size was close to the maximal size for $N$. puber found in the region (85 mm CW; Silva 2008), our data suggest that limpets $>40 \mathrm{~mm}$ may not be vulnerable to predation by $N$. puber.

\section{Expt 2: size preference}

The most frequent prey size eaten when there was no choice available was smaller than the prey size that was predominantly eaten when there was a choice. In Stage 1 of the experiment to establish the size preference for limpet prey (no choice available), smaller limpets were consumed more than larger limpets. This effect was consistent across all size-classes of crabs (Table 1). In the second stage of the experiment (when choice was available), there was a clear correspondence between crab size and the prey sizes consumed (Fig. 1). The largest crabs (21-25 mm major cheliped height) fed more frequently on $15-20$ and $25-30 \mathrm{~mm}$ limpet size-classes, while the smallest crabs (5-10 mm major cheliped height) mostly consumed limpets of the smallest size-class (5-10 mm). Intermediate size crabs (11-15 and 16-20 mm) fed predominantly on 15$20 \mathrm{~mm}$ limpets.

The proportion of prey sizes consumed when choice was present versus the proportions eaten when choice was absent are shown in Table 1. Almost all crab sizeclasses except for the smallest crabs $(\leq 10 \mathrm{~mm})$ displayed preferences for particular prey sizes, as there were significant differences in the observed prey consumption and the expected values under the null hypothesis of no preference $\left(\chi^{2}\right.$ test nos. 1 to 8 ; Table 1). The pattern was consistent and striking, that limpets of a size-class higher were preferentially con- 
Table 1. Expt 2. Summary of $\chi^{2}$ tests based on the height of the master chela of Necora puber and prey size. The $\chi^{2}$ statistic indicates whether the proportions of sizes consumed when choice was available differed to that when choice was absent. ns $=$ not significant; na = not applicable because limpets of those sizes had been previously been shown not to be vulnerable to tested crab sizes

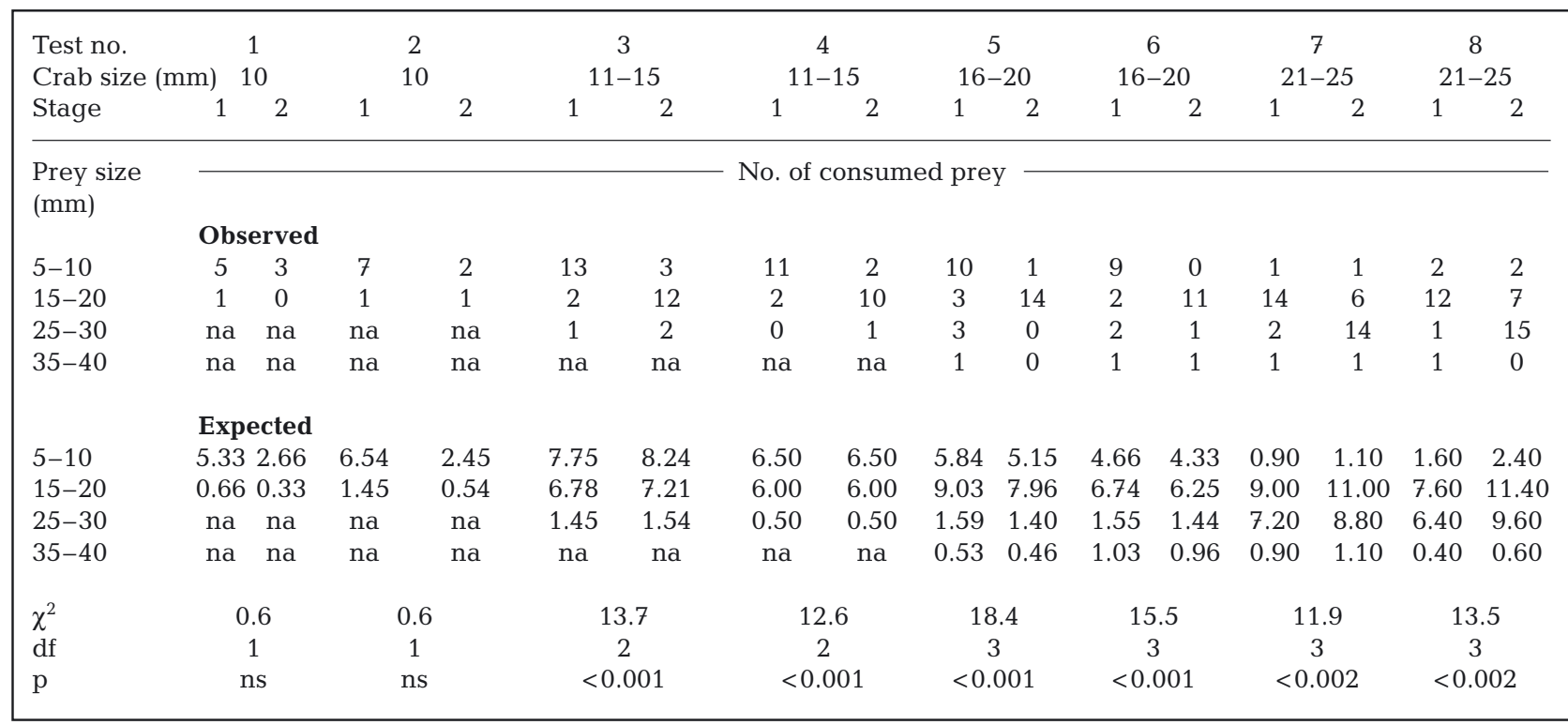

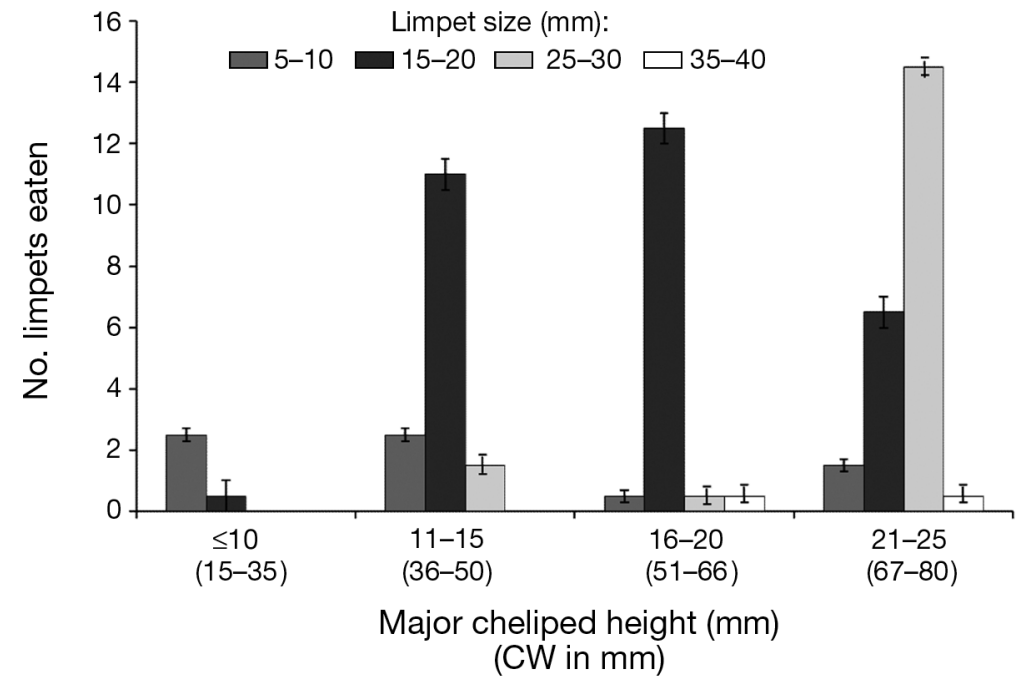

Fig. 1. Expt 2. Patella vulgata (average number \pm SE) eaten by Necora puber in Stage 2 (when choice was available) according to predator and prey size. Limpets $>40 \mathrm{~mm}$ were not eaten. CW: carapace width. $\mathrm{n}=2$

sumed when given a choice, than when given no choice. For all crab sizes, most of the limpets eaten were smaller than those that the crabs were actually able to handle. Crabs of size-classes 11-15 mm and 16-20 $\mathrm{mm}$ preferred limpets of the size-class 15-20 mm, while the largest crabs of the size-class 21-25 mm preferred limpets of the $25-30 \mathrm{~mm}$ sizeclass. This confirmed that Necora puber actively selected prey according to their size when choice for prey sizes was made available.

\section{Expt 3: predator handling behaviour and prey size}

Video observations indicated qualitative differences in Necora puber attack behaviour according to sizes of Patella vulgata, with the smallest limpets $(5-10 \mathrm{~mm})$ invariably being crushed across their width by crabs of all sizes. For larger limpets, crabs initially inserted the tip of the chela under the shell edge, then grasped and levered or pulled in order to detach the shell from the substratum. This last technique was more frequently used by smaller crabs attacking the smallest limpets, while larger individuals were readily able to crush limpet shells. There was a direct relationship between crab size and handling time, whereby crabs with larger master claws had shorter handling times for a given prey size, except for the largest limpet size-class when no difference was present between the 2 largest crab size-classes (Fig. 2).

\section{DISCUSSION}

Our study successfully controlled for experimental limitations that are often found in feeding preference studies (see Chesson 1978, Peterson \& Renaud 1989, Underwood et al. 2004, Underwood \& Clarke 2005, 


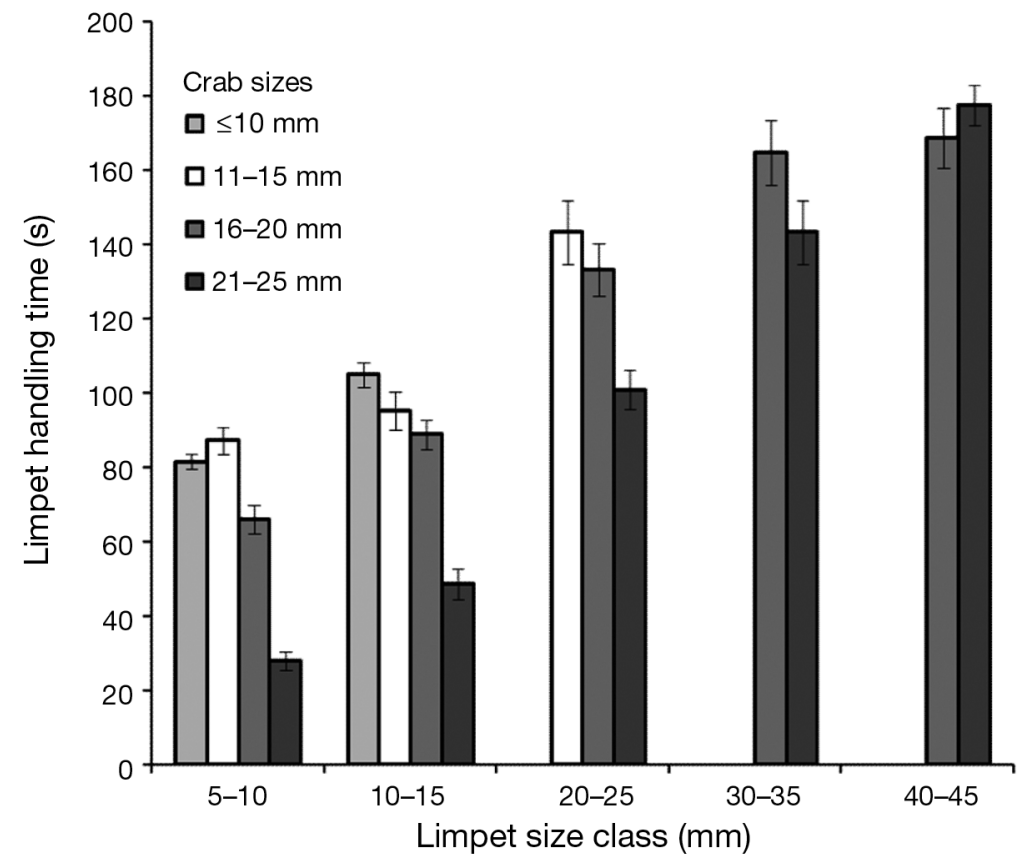

Fig. 2. Expt 3. Handling time (mean $\pm \mathrm{SE}$ ) required by Necora puber crabs of differing sizes to consume the tested limpet sizes (Patella vulgata)

large individuals (27-30 $\mathrm{mm}$ shell length) being resistant to crushing (ap Rheinallt 1986). In the present study, no lower limit in limpet size was found within the sizerange tested and all sizes $<41 \mathrm{~mm}$ were readily consumed by medium and large crabs. This could be a consequence of small limpets being readily crushed without the need for grasping.

From a predator perspective, and according to Yamada \& Boulding (1998), the upper limit in prey size in crab performance is related to mechanical constraints of the crab chela size (height or gape), musculature and dentition. It was apparent from our video observations that even the largest crab was unable to prise limpets $>41 \mathrm{~mm}$ from the rock. This suggests, from the perspective of prey, that the increase in tenacity (force of attachment per unit of foot area) with limpet size (Grenon \& Walker 1981) may be a decisive factor in determining prey vulnerability. Preference behaviour is frequently attributed to mechanical constraints imposed on predators due to

Jackson \& Underwood 2007), namely: (1) independent data sets were used for each experimental stage with single use of both predator and prey individuals, reducing the potential for changes in behaviour due to learning (Hughes \& Dunkin 1984); (2) there was no autogenic change or mortality in prey (i.e. food changes in the absence of consumers) that could influence the predator food choice (see Peterson \& Renaud 1989); (3) the predator-prey arena was standardised using natural rock; and (4) statistical analyses reflected the uncertainty in estimates from both stages of the 2-stage experiments (Underwood \& Clarke 2005).

The limpet Patella vulgata and the crab Necora puber provided a good model system to examine predator-prey size association between crabs and limpets. Our study demonstrated that $N$. puber were able to consume a wide spectrum of sizes of P. vulgata. However, there was a size refuge for $P$. vulgata $>41 \mathrm{~mm}$, which even the largest crabs (25 $\mathrm{mm}$ chela height) could not exploit. Our assessment of the limpet population structure in the field indicates that individuals $>40 \mathrm{~mm}$ represented only $6 \%$ of the population, implying that $N$. puber was able to eat the vast majority of the limpets. The existence of a maximum prey size that a crab can eat has been reported for other gastropod prey such as the snail Littorina sitkana Philippi (Yamada \& Boulding 1998). N. puber has been shown to have upper and lower size limits for consumption of the mussel Mytilus edulis L., with small individuals (<17 mm shell length) being difficult to grasp, and prey features such as overall size, thickness and strength (Juanes 1992). Crabs cannot maximise their energy intake by consuming large prey due to the probability of incurring damage or energy depletion as prey size increases. The only defensive limpet behaviour observed in the present study was shell clamping. This behaviour results in the shell tightly fitting to the substratum, preventing the crab from inserting its chela beneath the shell edge, which was a key step for successful removal of the limpet. A very tall or wide shell shape may also prevent a crab from using a crushing technique.

Comparisons between the number of prey consumed with and without a choice of sizes showed that Necora puber was selective in the size of Patella vulgata consumed. For all crab sizes, the dominant number of limpets eaten were in smaller size-classes than those the crabs were actually able to handle. Other studies on feeding behaviour have shown the same propensity for crabs to eat larger numbers of small sizes, within a viable size range (e.g. the dogwhelk Nucella lapillus L., the bivalve $M$. edulis; see review in Juanes 1992). It is likely that other predatory intertidal portunids may also consume larger numbers of small prey than the maximum prey sizes that could be tackled (e.g. Carcinus maenas, which has been shown to consume smaller mussels; Elner 1978, Hughes \& Elner 1979). It was interesting to find in the preference experiment that when offered a choice, crabs of most sizes consumed large prey in higher frequencies than when not 
offered a choice. Reasons for this can only be highly speculative, particularly because for other species of crabs, the opposite behaviour is commonly found, i.e. predators consume most prey smaller than that they can handle (Juanes 1992). It may be an optimal behaviour to attempt initial attacks on large prey when choice of sizes is available. Under optimal diet predictions (Hughes 1980), preference for prey is often a compromise between the energy expenditure involved in prey handling, encounter rates and energy gain from prey consumption. In the present study, large limpets required longer handling times and presumably more energy expenditure, but energy intake may compensate the energy expenditure and thus explain the consumption of large prey when in a choice scenario. When small prey are not available, it may no longer be optimal to spend the energy on a potentially fruitless attack on a large prey item, and this could explain why the numbers of large prey eaten in the Stage 1 trials were smaller. Alternatively, small limpets may not be the preferred prey based on their energy content since for instance, the gonadal tissue (high in lipid content; see Brazão et al. 2003) would be smaller in 15 to $25 \mathrm{~mm} P$. vulgata than for large individuals (>30 mm; Blackmore 1969). Hence, N. puber of most sizes foraging on the shore would be likely to choose 15 to $20 \mathrm{~mm}$ size limpets since these are common and are well within their mechanical ability.

Our work suggests that preference by intermediatesized crabs (11-15 $\mathrm{mm} \& 16-20 \mathrm{~mm}$ ) and large crabs (21-25 mm) for $15-20 \mathrm{~mm}$ and $25-30 \mathrm{~mm}$ limpets respectively may reduce the number of limpets of these size-classes in locations where Necora puber densities are high. In the present study, the average Patella vulgata size recorded in the intertidal zone was $18 \pm 0.3 \mathrm{~mm}$ and the most frequent size-class was $15-20 \mathrm{~mm}$. This indicates that the encounter rate of $N$. puber with its preferred prey size would be frequent. Previous work in southwest England using fixed traps has shown that up to $\sim 85 \mathrm{~N}$. puber can migrate into the intertidal zone $\left(1000 \mathrm{~m}^{2}\right)$ during a single high tide (Silva 2008), suggesting that these predators have the potential to exert a substantial effect on $P$. vulgata population structure. If predation removes individuals $<25 \mathrm{~mm}$, this may influence reproductive success, because these individuals are only just maturing and are mostly male (Blackmore 1969). Hence, size-selective predation may affect the reproductive balance within a population. Such predatory effects will be dependent on predator density, but could be important because the reproductive success and recruitment of limpets is notoriously variable (Bowman \& Lewis 1977, Bowman 1985). Hence, in years with little recruitment, predation effects may be considerable.
Selective foraging by Necora puber could also modulate other biological interactions that are important for the ecology of intertidal habitats. For example, intraspecific competition is considerable in Patella spp. and is dependent on limpet density. Hence, if the frequency of various size-classes is altered by predation, this could affect intraspecific competitive balances (see Boaventura et al. 2002b, 2003). Species such as limpets rely on armour and behaviour (e.g. clamping and aggregation) to persist in the face of intense predation (Vermeij 1987, 1994, Coleman et al. 2004); there is no low-density refuge from predation such as that observed in deep-dwelling infaunal bivalves (Seitz et al. 2001). In years of low recruitment, limpets will suffer proportionally higher mortality rates and possible local extinction (see a conceptual model for bivalves in Seitz et al. 2001), if there are insufficient numbers of large limpets able to evade predation and reproduce successfully.

A limitation of the present study was the extent of its applicability to the field (e.g. Crowe \& Underwood 1998). As far as possible we mimicked natural conditions, for example by using natural rock in the trial arenas. However, field experiments would be required to establish the importance of crab behaviour and assess the extent of the size-specific predatory impact of Necora puber and other decapods on natural patellid populations.

Acknowledgements. We thank R. Ticehurst and A. Torr for the help in collecting the experimental animals and in the setup of the feeding trials. K.R.C. acknowledges his honorary position at the Plymouth Marine Laboratory and the Marine Biological Association, UK, and at Murdoch University, Western Australia. This work and A.C.S. were supported by the 'Fundação para a Ciência e Tecnologia', Portugal (PhD grant SFRH/BD/19077/2004). S.J.H. was supported by a Natural Environment Research Council (NERC) grant in aid and the Oceans 2025 programme (Theme 4).

\section{LITERATURE CITED}

ap Rheinallt T (1986) Size selection by the crab Liocarcinus puber feeding on mussels Mytilus edulis and on shore crabs Carcinus maenas: the importance of mechanical factors. Mar Ecol Prog Ser 29:45-53

Blackmore DT (1969) Studies of Patella vulgata L. I. Growth, reproduction and zonal distribution. J Exp Mar Biol Ecol 3:200-213

Boaventura D, Alexander M, Della Santina P, Smith ND, Ré P, Cancela da Fonseca L, Hawkins SJ (2002a) The effects of grazing on the distribution and composition of low-shore algal communities on the central coast of Portugal and on the southern coast of Britain. J Exp Mar Biol Ecol 267: 185-206

> Boaventura D, Cancela da Fonseca L, Hawkins SJ (2002b) Analysis of competitive interactions between the limpets Patella depressa Pennant and Patella vulgata L. on the northern coast of Portugal. J Exp Mar Biol Ecol 271:171-188 
Boaventura D, Cancela da Fonseca L, Hawkins SJ (2003) Size matters: competition within populations of the limpet Patella depressa. J Anim Ecol 72:435-446

Bowman RS (1985) The biology of the limpet Patella vulgata L. in the British Isles: spawning time as a factor determining recruitment success. In: Moore PG, Seed R (eds) Ecology of the rocky coasts. Hodder and Stoughton, London, p 178-815

Bowman RS, Lewis JR (1977) Annual fluctuations in the recruitment of Patella vulgata L. J Mar Biol Assoc UK 57: 793-815

- Brazão S, Morais S, Boaventura D, Ré P, Narciso L, Hawkins SJ (2003) Spatial and temporal variation of the fatty acid composition of Patella spp. (Gastropoda: Prosobranchia) soft bodies and gonads. Comp Biochem Physiol B 136: 425-441

Cannicci S, Fratini S, Vannini M (1999) Use of time, space and food resources in the mangrove climbing crab Selatium elongatum (Grapsidae: Sesarminae). Mar Biol 135: 335-339

> Cannicci S, Gomei M, Boddi B, Vannini M (2002) Feeding habits and natural diet of the intertidal crab Pachygrapsus marmoratus: opportunistic browser or selective feeder? Estuar Coast Shelf Sci 54:983-1001

> Chesson J (1978) Measuring preference in selective predation. Ecology 59:211-215

> Chilton NB, Bull CM (1984) Influence of predation by a crab on the distribution of the size-groups of three intertidal gastropods in South Australia. Mar Biol 83:163-169

> Chilton NB, Bull CM (1986) Size-related selection of two intertidal gastropods by the reef crab Ozius truncatus. Mar Biol 93:475-480

Clark PF (1986) North-east Atlantic crabs; an atlas of distribution. Marine Conservation Society, Ross-on-Rye

> Coleman RA, Browne M, Theobalds T (2004) Aggregation as a defense: limpet tenacity changes in response to simulated predator attack. Ecology 85:1153-1159

Coleman RA, Underwood AJ, Benedetti-Cecchi L, Aberg P and others (2006) A continental scale evaluation of the role of limpet grazing on rocky shores. Oecologia 147:556-564

> Crowe TP, Underwood AJ (1998) Testing behavioural 'preference' for suitable microhabitat. J Exp Mar Biol Ecol 225: $1-11$

Elner RW (1978) The mechanisms of predation by the shore crab, Carcinus maenas (L.), on the edible mussel, Mytilus edulis L. Oecologia 36:333-344

Elner RW, Raffaelli DG (1980) Interactions between two marine snails, Littorina rudis Maton and Littorina nigrolineata Gray, a predator, Carcinus maenas (L.) and a parasite, Microphallus similis Jägerskiold. J Exp Mar Biol Ecol 43:151-160

Freire J (1996) Feeding ecology of Liocarcinus depurator (Decapoda:Portunidae) in the Ría de Arousa (Galicia, north-west Spain): effects of habitat, season and life history. PSZN I: Mar Ecol 126:297-311

Freire J, Sampedro MP, González-Gurriarán E (1996) Influence of morphometry and biomechanics on diet selection in three portunid crabs. Mar Ecol Prog Ser 137:111-121

Grenon J, Walker G (1981) The tenacity of the limpet, Patella vulgata L.: an experimental approach. J Exp Mar Biol Ecol 54:277-308

Hawkins S, Hartnoll R (1983) Grazing of intertidal algae by marine invertebrates. Oceanogr Mar Biol Annu Rev 21: 195-282

Hawkins SJ, Hartnoll RG, Kain JM, Norton TA (1992) Plantanimal interactions in the marine benthos. In: John DM, Hawkins SJ, Price JH (eds) Plant-animal interactions on hard substrata in the north-east Atlantic, Vol 46. Clarendon Press, Oxford, p 1-32

Hughes RN (1980) Optimal foraging theory in the marine context. Oceanogr Mar Biol Annu Rev 18:423-481

Hughes RN (2000) Crab claws as tools and weapons. In: Domenici P, Blake RW (eds) Biomechanics in animal behavior. BIOS Scientific, Oxford, p 195-205

Hughes RN, Dunkin SB (1984) Effect of dietary history on selection of prey, and foraging behaviour among patches of prey, by the dogwhelk, Nucella lapillus (L.). J Exp Mar Biol Ecol 79:159-172

Hughes RN, Elner RW (1979) Tactics of a predator, Carcinus maenas, and morphological responses of the prey Nucella lapillus. J Anim Ecol 48:6-78

Hughes RN, Seed R (1981) Size selection of mussels by the blue crab Callinectes sapidus: energy maximizer or time minimizer? Mar Ecol Prog Ser 6:83-89

> Hughes RN, Seed R (1995) Behavioural mechanisms of prey selection in crabs. J Exp Mar Biol Ecol 193:225-238

> Hunter E, Naylor E (1993) Intertidal migration by the shore crab Carcinus maenas. Mar Ecol Prog Ser 101:131-138

> Iwasaki K (1993) Analyses of limpet defense and predator offense in the field. Mar Biol 116:277-289

Jackson AC, Underwood AJ (2007) Application of new techniques for the accurate analysis of choice of prey. J Exp Mar Biol Ecol 341:1-9

Jenkins SR, Coleman RA, Della Santina P, Hawkins SJ, Burrows MT, Hartnoll RG (2005) Regional scale differences in the determinism of grazing effects in the rocky intertidal. Mar Ecol Prog Ser 287:77-86

Juanes F (1992) Why do decapod crustaceans prefer smallsized molluscan prey? Mar Ecol Prog Ser 87:239-249

Lee S, Seed R (1992) Ecological implications of cheliped size in crabs: some data from Carcinus maenas and Liocarcinus holsatus. Mar Ecol Prog Ser 84:151-160

> Lowell RB (1986) Crab predation on limpets: predator behaviour and defensive features of the shell morphology of the prey. Biol Bull 171:577-596

> Manly BFJ (2006) On a proposed method for analysing experiments on food choice. J Exp Mar Biol Ecol 335:154-155

> Mascaró M, Seed R (2001) Foraging behaviour of juvenile Carcinus maenas (L.) and Cancer pagurus L. Mar Biol 139:1135-1145

Menge BA, Sutherland JP (1976) Species diversity gradients: synthesis of the roles of predation, competition, and temporal heterogeneity. Am Nat 110:351-369

Menge BA, Sutherland JP (1987) Community regulation: variation in disturbance, competition, and predation in relation to environmental stress and recruitment. Am Nat 130:730-757

> Moore P, Hawkins SJ, Thompson RC (2007) Role of biological habitat amelioration in altering the relative responses of congeneric species to climate change. Mar Ecol Prog Ser 334:11-19

Naylor E (1958) Tidal and diurnal rhythms of locomotory activity in Carcinus maenas (L.). J Exp Biol 35:602-610

Norman CP, Jones MB (1992) Influence of depth, season and moult stage on the diet of the velvet swimming crab Necora puber (Brachyura, Portunidae). Estuar Coast Shelf Sci 34:71-83

Peterson CH, Renaud PE (1989) Analysis of feeding preference experiments. Oecologia 80:82-86

Seed R, Hughes RN (1995) Criteria for prey size-selection in molluscivorous crabs with contrasting claw morphologies. J Exp Mar Biol Ecol 193:177-195

Seed R, Hughes RN (1997) Chelal characteristics and foraging behaviour of the blue crab Callinectes sapidus Rathbun. Estuar Coast Shelf Sci 44:221-229 
Seitz RD, Lipcius RN, Hines AH, Eggleston DB (2001) Density-dependent predation, habitat variation, and the persistence of marine bivalve prey. Ecology 82:2435-2451

Sih A, Crowley P, McPeek M, Petranka J, Strohmeier K (1985) Predation, competition, and prey communities: a review of field experiments. Annu Rev Ecol Syst 16:269-331

Silva ACF (2008) Predation by crabs on rocky shores in NorthEast Atlantic. PhD thesis, University of Plymouth

Silva ACF, Boaventura DM, Flores A, Ré P, Hawkins SJ (2004) Rare predation by the intertidal crab Pachygrapsus marmoratus on the limpet Patella depressa. J Mar Biol Assoc UK 84:367-370

Silva ACF, Hawkins SJ, Boaventura DM, Thompson RC (2008) Predation by small mobile aquatic predators regulates populations of the intertidal limpet Patella vulgata (L.). J Exp Mar Biol Ecol 367:259-265

Singer MC (2000) Reducing ambiguity in describing plantinsect interactions: 'preference', 'acceptability' and 'electivity'. Ecol Lett 3:159-162

Taplin RH (2007) Experimental design and analysis to investigate predator preferences for prey. J Exp Mar Biol Ecol 344:116-122

Thompson RC, Norton TA, Hawkins SJ (2004) Physical stress and biological control regulate the producer-consumer balance in intertidal biofilms. Ecology 85:1372-1382

Underwood AJ, Clarke KR (2005) Solving some statistical problems in analyses of experiments on choices of food

Editorial responsibility: Romuald N. Lipcius,

Virginia, USA and on associations with habitat. J Exp Mar Biol Ecol 318: $227-237$

> Underwood AJ, Clarke KR (2006) Response on a proposed method for analysing experiments on food choice. J Exp Mar Biol Ecol 335:151-153

Underwood AJ, Clarke KR (2007) More response on a proposed method for analysing experiments on food choice. J Exp Mar Biol Ecol 344:113-115

> Underwood AJ, Chapman MG, Crowe TP (2004) Identifying and understanding ecological preferences for habitat or prey. J Exp Mar Biol Ecol 300:161-187

> Vermeij GJ (1977) Patterns in crab claw size: the geography of crushing. Syst Zool 26:138-151

Vermeij GJ (1978) Biogeography and adaptation: patterns of marine life. Harvard University Press, Cambridge, MA

Vermeij GJ (1987) Evolution and escalation: an ecological history of life. Princeton University Press, Princeton, NJ

Vermeij GJ (1994) The evolutionary interaction among species: selection, escalation and coevolution. Annu Rev Ecol Syst 25:219-236

> Vermeij GJ, Schindel DE, Zipser E (1981) Predation through geological time: evidence from gastropod shell repair. Science 214:1024-1026

Yamada SB, Boulding EG (1998) Claw morphology, prey size selection and foraging efficiency in generalist and specialist shell-breaking crabs. J Exp Mar Biol Ecol 220: $191-211$

Submitted: October 28, 2009; Accepted: August 22, 2010 Proofs received from author(s): October 4, 2010 